\title{
Phytoprotection
}

\section{A note on the antibiotic properties of Bacillus subtilis against Colletotrichum trifolii}

\section{Y. Douville et J.G. Boland}

Volume 73, numéro 1, 1992

URI : https://id.erudit.org/iderudit/706018ar

DOI : https://doi.org/10.7202/706018ar

Aller au sommaire du numéro

Éditeur(s)

Société de protection des plantes du Québec (SPPQ)l

ISSN

0031-9511 (imprimé)

1710-1603 (numérique)

Découvrir la revue

Citer cet article

Douville, Y. \& Boland, J. (1992). A note on the antibiotic properties of Bacillus subtilis against Colletotrichum trifolii. Phytoprotection, 73(1), 31-36.

https://doi.org/10.7202/706018ar
Résumé de l'article

On a étudié l'influence et les mécanismes d'action in vitro et in vivoBacillus subtilissur le Colletotrichum trifolii, un champignon causant l'anthracnose de la luzerne (Medicago sativa). Lors d'essais en chambre de culture, l'application du filtrat du bouillon nutritif du $B$. subtilis a réduit significativement l'incidence et la gravité de la maladie de respectivement 56 à $16 \%$ et de 2,0 à 1,2 . L'application de cellules lavées du B. subtilis n'a pas entraîné une diminution de l'incidence et de la gravité de la maladie. Sur les folioles de la luzerne, le filtrat a causé une réduction de la germination des conidies, la lyse des conidies et une formation réduite d'appressoriums. In vitro, il a réduit la germination des conidies, induit la lyse des conidies et la formation de tubes germinatifs enflés. Un antibiotique de la famille des iturines, l'iturine $D$, serait l'agent actif dans la suppression du $C$. trifolii par le $B$. subtilis. 


\title{
A note on the antibiotic properties of Bacillus subtilis against Colletotrichum trifolii
}

\author{
Y. Douville ${ }^{1}$ and G.J. Boland ${ }^{1,2}$
}

Received 1991-11-07; accepted 1992-06-18

\begin{abstract}
The influence and mechanisms of action of Bacillus subtilis on Colletotrichum trifolii, a causal agent of anthracnose of alfalfa (Medicago sativa), were studied in vivo and in vitro. In growth room conditions, a cell-free culture filtrate of $B$. subtilis significantly reduced disease incidence and severity on alfalfa seedlings from $56 \%$ to $16 \%$ and from 2.0 to 1.2 , respectively. Treatment of seedlings with washed cell suspensions of $B$. subtilis had no influence on disease. Applications of crude filtrate on alfalfa leaflets inoculated with $C$. trifolii were associated with reduced germination of conidia, lysis of conidia, and reduced formation of appressoria. Under in vitro conditions, crude filtrate reduced germination of conidia, and induced lysis of conidia and the formation of inflated germ tubes on germinating conidia. An antibiotic of the iturin family, iturin D, was tentatively identified as the active compound responsible for the suppressive effect of $B$. subtilis on C. trifolii.
\end{abstract}

Douville, Y., and G.J. Boland. 1992. A note on the antibiotic properties of Bacillus subtilis against Colletotrichum trifolii. PHYTOPROTECTION 73: 31-36.

On a étudié l'influence et les mécanismes d'action in vitro et in vivo du Bacillus subtilis sur le Colletotrichum trifolii, un champignon causant l'anthracnose de la luzerne (Medicago sativa). Lors d'essais en chambre de culture, I'application du filtrat du bouillon nutritif du $B$. subtilis a réduit significativement l'incidence et la gravité de la maladie de respectivement 56 à $16 \%$ et de 2,0 à 1,2. L'application de cellules lavées du $B$. subtilis n'a pas entraîné une diminution de l'incidence et de la gravité de la maladie. Sur les folioles de la luzerne, le filtrat a causé une réduction de la germination des conidies, la lyse des conidies et une formation réduite d'appressoriums. In vitro, il a réduit la germination des conidies, induit la lyse des conidies et la formation de tubes germinatifs enflés. Un antibiotique de la famille des iturines, l'iturine D, serait l'agent actif dans la suppression du C. trifolii par le B. subtilis.

Anthracnose, caused primarily by Colletotrichum trifolii Bain \& Essary, is a highly destructive disease of alfalfa (Medicago sativa L.) that is most prevalent in the southern and mid-Atlantic regions of the United States but also occurs in many other regions of the world (Elgin et al. 1981;

1. Department of Environmental Biology, University of Guelph, Guelph, Ontario, Canada N1G 2W1

2. Author to whom correspondence should be addressed
Michaud et al. 1988). The pathogen is responsible for stand thinning (Jones et al. 1978), yield reduction (Elgin etal. 1981) and predisposition to winter injury (Barnes et al. 1969). In Canada, C. trifolii has been reported on alfalfa in eastern Ontario (Basu 1983) and on clover (Trifolium spp.) in Prince Edward Island (Willis 1965). In Ontario, anthracnose is caused primarily by $C$. destructivum $\mathrm{O}^{\prime}$ Gara (Boland and Brochu 1989).

Recently, the potential for biological control of anthracnose using microor- 
ganisms that were originally selected for efficacy against other foliar plant pathogens was examined (Douville 1990; Douville and Boland 1989; Douville et al. 1990). Of 11 microorganisms that were evaluated for the ability to suppress anthracnose of alfalfa in greenhouse trials, one isolate of Bacillus subtilis (Ehrenberg) Cohn was shown to reduce the severity of disease on a susceptible cultivar. The objectives of this study were to investigate the influence and mechanisms of action of the observed suppression of $C$. trifolii by $B$. subtilis.

The isolate of $B$. subtilis used in this study was isolated from soil by Dr. B.H. MacNeil, University of Guelph. Agar cultures were grown on potato dextrose agar (PDA) at $22-25^{\circ} \mathrm{C}$ for $5-7 \mathrm{~d}$ in the dark. Liquid suspension cultures were grown by transferring inoculum from an activelygrowing culture on PDA to $100 \mathrm{~mL}$ of potato dextrose broth (PDB) in a $250 \mathrm{~mL}$ erlenmeyer flask. Liquid suspension cultures were incubated for $48 \mathrm{~h}$ on a rotary shaker at $100 \mathrm{r} \mathrm{min}^{-1}$. For experimental treatments, cell suspensions of $B$. subtilis were prepared by adjusting the concentration of cells to $1 \times 10^{8} \mathrm{cfu} \mathrm{mL}^{-1}$ using a spectrophotometer at $660 \mathrm{~nm}$. Washed cell suspensions were prepared similarly except that cells were centrifuged and resuspended three times consecutively at $15000 \mathrm{~g}$ for $20 \mathrm{~min}$ in a Sorvall RC2-B centrifuge. Cell-free crude filtrate was prepared from liquid suspension cultures by centrifugation at $15000 \mathrm{~g}$ for $20 \mathrm{~min}$ in a Sorvall RC2-B centrifuge. The supernatant was then filtered through a $0.22 \mu \mathrm{m}$ filter to obtain an undiluted cell-free crude filtrate of the bacterium. Unless indicated otherwise, all crude filtrates were adjusted to $\mathrm{pH} 7.2$ before use.

Colletotrichum trifolii (race 1) was obtained from the American Type Culture Collection (\# 42881) and was cultured on PDA at $22-25^{\circ} \mathrm{C}$ for $7-10 \mathrm{~d}$. Conidia were harvested by washing the surface of the culture with sterile deionized water amended with $0.01 \%$ Tween 20 (Fisher Scientific). The concentration of conidia in the resulting suspensions was adjusted to $2 \times 10^{5}$ spores $\mathrm{mL}^{-1}$ using a haemocytometer.

Alfalfa seedlings (cv. Saranac) were grown for $21 \mathrm{~d}$ in a growth room main- tained at $22-25^{\circ} \mathrm{C}$ with a $16 \mathrm{~h} \mathrm{~d}^{-1}$ photoperiod to study the influence of $B$. subtilis on disease incidence. In the first growth room experiment, $25 \mathrm{~mL}$ of washed cell suspension of $B$. subtilis and $25 \mathrm{~mL}$ of undiluted crude filtrate were individually applied to 48 plants. A control treatment of $25 \mathrm{~mL}$ of deionized water amended with $0.01 \%$ Tween 20 was also applied. In the second growth room experiment, $20 \mathrm{~mL}$ each of washed cell suspension and undiluted crude filtrate were applied to 60 plants. Immediately after application of the treatments, the plants were covered with plastic bags for $24 \mathrm{~h}$ to allow the bacterial population to stabilize. The bags were then removed and the plants were challenge-inoculated with $20 \mathrm{~mL}$ of $2 \times 10^{5}$ conidia $\mathrm{mL}^{-1}$ of $C$. trifolii. The plants were enclosed in plastic bags for an additional $48 \mathrm{~h}$ and were evaluated for disease incidence and severity $14 \mathrm{~d}$ following application of the pathogen. Treatments were arranged in a randomized complete block experimental design with eight and six replications in the first and second experiments, respectively. Seedlings were individually rated for disease severity on a scale of 1-5 where: $1=$ healthy plants and $5=$ dead plant (Ostazeski et al. 1969). The mean disease severity of plants within each replication was used to calculate a disease severity index (DSI) for each treatment. Disease incidence was expressed as the percentage of plants with disease symptoms compared to the number of plants evaluated. Disease severity and incidence values were transformed for statistical analysis using the arcsin square root transformation to improve normality and homogeneity of variances. Means were separated by a protected LSD test (Snedecor and Cochran 1980).

To determine the influence of $B$. subtilis on the pathogen, leaflets from plants sprayed with water (control) and with crude filtrate of $B$. subtilis were examined $48 \mathrm{~h}$ after inoculation with $C$. trifolii. Leaflets were placed on a glass microscope slide, covered with a coverslip, and stained with lactophenol-cotton blue. Conidia of $C$. trifolii were observed at random under $400 \mathrm{X}$ magnification and the percentage of germinated conidia was determined. A conidium was consiclered germinated if the germ tube was longer 
than one-half the length of the conidium. The percentage of total conidia (ungerminated + germinated) and the percentage of germinated conidia that produced appressoria were also determined. At least 100 conidia were evaluated in each repetition of the control treatments and at least 60 conidia in each of the crude filtrate treatments.

Aliquots of the crude filtrate were diluted with sterile distilled water to final concentrations of $0,3.3,13.3,33.3$ and $100 \%$ to assay the activity of the crude filtrate in vitro. Each dilution was adjusted to $\mathrm{pH}$ 7.2. Experimental treatments consisted of $10 \mu \mathrm{L}$ of each of the crude filtrate dilutions mixed with $10 \mu \mathrm{L}$ of a $2 \times 10^{5}$ conidia $\mathrm{mL}^{-}$ ${ }^{1}$ suspension of $C$. trifoliion $2 \%$ water agar. A control treatment consisted of $10 \mu \mathrm{L}$ deionized water mixed with $10 \mu \mathrm{L}$ of spore suspension of $C$. trifolii. One-hundred conidia in each of four replications were evaluated for the percentage of germination, morphological abnormalities, and cytological damage after 6 and $18 \mathrm{~h}$ of incubation. Additional observations were made after 48 and $72 \mathrm{~h}$ of incubation.

Crude filtrate was fractionated according to molecular weight in Sephadex G-25 gel (Nap-25, Pharmacia). The fractionation range was $1000-5000 \mathrm{Da}$. Fractions of 0.5$1.5 \mathrm{~mL}$ were collected and individually bioassayed using the method described previously. Control treatments consisted of conidia of $C$. trifolii in water or in crude filtrate.

To concentrate and extract active compounds, $1.2 \mathrm{~L}$ of the crude filtrate were precipitated by adjusting to $\mathrm{pH} 2.5$ with 3 $M \mathrm{HCl}$ (Gueldner et al. 1988; Vanittanakom et al. 1986). The precipitate was collected by centrifugation at $10000 \mathrm{~g}$ for $10 \mathrm{~min}$ and then extracted twice with $100 \%$ ethanol. The extract was centrifuged at $4000 \mathrm{~g}$ for $5 \mathrm{~min}$ and the precipitate was discarded. The supernatant was concentrated to a volume of approximately 10 $\mathrm{mL}$ by evaporation at $60^{\circ} \mathrm{C}$.

The concentrated solution was spotted onto silica gel-60 F-254 TLC strips (Mandel Scientific). Each strip was developed in solvent $A$ (chloroform:methanol:water $65: 25: 4)$ for a distance of $15 \mathrm{~cm}$. The TLC strip was then cut horizontally in sections of $1 \mathrm{~cm}$. For the detection of biological activity, each section was placed at a distance of $4 \mathrm{~cm}$ from a 6 -mm-diam agar plug of $C$. trifolii on a $5-\mathrm{cm}$-diam plastic Petri dish containing PDA medium. The presence of a clear zone of inhibition in the developing colony of $C$. trifolii was monitored over a period of several days.

The concentrated filtrate was also examined with two-dimensional chromatography using solvents $A$ and $B$ (butanol: acetone:water 4:6:1). Compounds were detected using an UV lamp at $254 \mathrm{~nm}$, and by application of a solution of ninhydrin that was then developed at $110^{\circ} \mathrm{C}$ for 10 min to detect free amino groups (Winkelmann et al. 1983). Compounds which are insoluble in water, such as lipids, were detected by spraying the plates with water (Bobitt 1963). Rf values of detected compounds were compared with published Rf values of antibiotics obtained under similar experimental conditions (Besson and Michel 1988; Ebata et al. 1969; Schreiber et al. 1988; Vanittanakom et al. 1986). Rf values were considered to be the same if they were within 0.02 units. All experiments were conducted at least twice.

Applications of washed cells of $B$. subtilis to 3-wk-old seedlings of alfalfa did not result in a significant reduction of anthrac-

Table 1. Effect of washed cells and crude filtrate of Bacillus subtilis on incidence and severity of anthracnose of alfalfa ${ }^{a}$

\begin{tabular}{lcc}
\hline Treatment & Incidence & Severity $^{\mathrm{b}}$ \\
\hline Control (water) & $56 \mathrm{a}$ & $2.0 \mathrm{a}^{\mathrm{c}}$ \\
Washed cells & $67 \mathrm{a}$ & $2.1 \mathrm{a}$ \\
Crude filtrate & $16 \mathrm{~b}$ & $1.2 \mathrm{~b}$ \\
\hline
\end{tabular}

a Three-wk-old alfalfa seedlings (cv. Saranac) were sprayed with $25 \mathrm{~mL}$ of crude filtrate or a washed suspension of $1 \times 10^{8} \mathrm{cfu} \mathrm{mL}^{-1}$ of $B$. subtilis. Seedlings were then challenge inoculated $24 \mathrm{~h}$ later with $20 \mathrm{~mL}$ of $2 \times 10^{5}$ conidia $\mathrm{mL}^{-1}$ of $C$. trifolii.

b Mean disease severity index of 108 plants that were evaluated $14 \mathrm{~d}$ after pathogen inoculation using a 1 to 5 scale where: $1=$ healthy plant and $5=$ dead plant.

c Means were transformed with an arcsin square root transformation for statistical analyses. Means within a column followed by the same letter are not significantly different $(P=0.05)$ according to a protected Least Significant Difference (LSD) test. 
and after $18 \mathrm{~h}\left(R^{2}=0.96\right)$. The percentage of germinated conidia in the undiluted crude filtrate was $20.5 \%$ after $6 \mathrm{~h}$ and $38 \%$ after $18 \mathrm{~h}$. Corresponding values for the control treatments after 6 and $18 \mathrm{~h}$ were 65.7 and $92.2 \%$, respectively.

In addition, the percentage of germinated conidia that formed appressoria was reduced by the presence of the filtrate. No disturbance of orientation, morphology, or colour of appressoria was observed. It appears, therefore, that the germ tubes were primarily affected in their ability to produce appressoria. It is clear that germ tubes were affected by the crude filtrate as approximately $50 \%$ of the germinated conidia had inflated germ tubes $(20-30 \mu \mathrm{m}$ in diam) in vitro after $6 \mathrm{~h}$, and $90 \%$ after $18 \mathrm{~h}$. The concentration of crude filtrate did not have a significant effect on the percentage of germinated conidia that developed inflated germ tubes (Figure 1b). Although inflated hyphae were rarely observed on leaves, it is possible that active substances, while not inducing inflated germ tubes on leaf surfaces, disrupted the development of germ tubes sufficiently to decrease the formation of appressoria. Induction of inflated germ tubes by $B$. subtilis has been reported against several fungi, including Sclerotiorum cepivorum (Backhouse and Stewart 1989), Colletotrichum falcatum Went (Vasudeva et al. 1958) and Alternaria daturae Peck (Rai 1975).

The fungicidal influence of filtrate of $B$. subtilis is supported by a $50 \%$ reduction in the number of conidia that were well stained on filtrate-treated plants. Ungerminated, non-staining conidia without cytoplasmic contents were commonly observed, especially after $48 \mathrm{~h}$ exposure to filtrate. In addition, lysis of conidia was observed during the in vivo test. Similarly, Baker et al. (1985) observed that the cytoplasm of about $30 \%$ of the conidia of Uromyces appendiculatus (Pers.:Pers.) Ung [syn.: U. phaseoli] had ballooned after application of $B$. subtilis on plants.

Two active fractions that suppressed germination of conidia were obtained following Sephadex column chromatography of crude filtrate but only one active compound from the combined $4.5-9.5 \mathrm{~mL}$ of eluate was detected using a bioauto- gram on PDA following thin-layer chromatography of semi-purified crude extract. The identification of antibiotic compounds within crude filtrate of $B$. subtilis by $\mathrm{pH}$ precipitation, ethanol extraction, and thin layer chromatography produced 10-12 detectable bands. However, when individual bands were assayed for activity against $C$. trifolii, a zone of inhibition of 10 $\mathrm{mm}$ was evident only for the compound corresponding to $\mathrm{Rf}$ values of $0.18-0.22$ in solvent $A$. This compound was ninhydrin negative and water positive.

Similarly, crude filtrate was examined for potential antibiotic compounds using two-dimensional, thin-layer chromatography in solvents $A$ and $B$. The active compound identified in the previous studies had $R f$ values of $0.17-0.20$ in solvent $A$ and $0.33-0.38$ in solvent $B$. The compound was ninhydrin negative and water positive.

The $\mathrm{Rf}$ values obtained for the active compound identified in the crude filtrate of $B$. subtilis are similar to values obtained for a known antibiotic produced by $B$. subtilis, iturin $\mathrm{D}(\mathrm{Rf}=0.18$ in solvent $A$, 0.35 in solvent $B$ ). None of the remaining compounds that were detected on the TLC studies possessed $\mathrm{Rf}$ values similar to other known antibiotics produced by $B$. subtilis (e.g. other iturins, bacillomycins, BS1, bacilysin or mycosubtilin). Iturin $D$ is also characterized as ninhydrin negative, water positive, and active against filamentous fungi (Besson and Michel 1987). Therefore, we conclude that at least one of the active components of crude filtrate of $B$. subtilis used in these studies is the antibiotic iturin $D$.

It is possible that the second active compound from the combined $1.0-3.5 \mathrm{~mL}$ of eluate was lost or degraded during the $\mathrm{pH}$ precipitation and ethanol extraction purification. Another possibility is that the activity of the second active compound is nutrient dependent and therefore would be less inhibitory in the bioautogram on PDA, which is a nutrient-rich medium.

We wish to thank Dr. B.H. MacNeil, University of Guelph, for providing the isolate of $B$. subtilis, M. Bom for technical assistance and suggestions, and the $\mathrm{Na}$ tural Sciences and Engineering Research Council for financial assistance. 


\section{REFERENCES}

Backhouse, D., and A. Stewart. 1989. Ultrastructure of antagonism of Sclerotiorum cepivorum by Bacillus subtilis. J. Phytopathol. 124: 207-214.

Baker, C.J., J.R. Stavely, and N. Mock. 1985. Biocontrol of bean rust by Bacillus subtilis under field conditions. Plant Dis. 69: 770772.

Barnes, D.K., S.A. Ostazeski, J.A. Schillinger, and C.H. Hanson. 1969. Effect of anthracnose (Colletotrichum trifolii) infection on yield, stand and vigor of alfalfa. Crop Sci. 9: 344-346.

Basu, P.K. 1983. Survey of eastern Ontario alfalfa fields to determine common fungal diseases and predominant soil-borne species of Pythium and Fusarium. Can. Plant Dis. Surv. 63: 51-54.

Besson, F., and G. Michel. 1987. Isolation and characterization of new iturins: iturin D and iturin E. J. Antibiot. 40: 437-442.

Besson, F., and G. Michel. 1988. Bacillomycins $F_{b}$ and $F_{c}$ : isolation and characterization. J. Antibiot. 41: 282-288.

Bobitt, J.M. 1963. Thin-layer chromatography. Reinhold Publishing Corporation, NewYork. $208 \mathrm{pp}$.

Boland, G.J., and L.D. Brochu. 1989. Colletotrichum destructivum on alfalfa in Ontario and cultivar response to anthracnose. Can. J. Plant Pathol. 11: 303-307.

Douville, Y. 1990. Biological suppression of anthracnose of alfalfa by Bacillus subtilis. M.Sc. Thesis, University of Guelph, Guelph, Ontario. $118 \mathrm{pp}$.

Douville, Y., and G.J. Boland. 1989. Germination and infection of Colletotrichum trifolii in vitro with Bacillus subtilis and in vivo on alfalfa leaflets. Phytoprotection 70: 143 (Abstract)

Douville, Y., C. Richard, and S. Pouleur. 1990. Possibilités de lutte biologique contre les maladies du feuillage et des tiges de la luzerne. Can. Plant Dis. Surv. 70: 5-9.

Ebata, M., K. Miyazaki, and Y. Takahashi. 1969. Studies on subsporin. I. Isolation and characterization of subsporins $A, B$ and $C$. J. Antibiot. 22: 467-472.

Elgin, J.H., Jr., D.K. Barnes, T.H. Busbice, G.R. Buss, N.A. Clark, R.W. Cleveland, R.L. Ditterline, D.W. Evans, S.C. Fransen, R.D. Horrocks, O.J. Hunt, W.R. Kehr, C.C. Lowe, D.A. Miller, M.S. Offutt, R.C. Pickett, E.L. Sorensen, C.M. Taliaferro, M.B. Tesar, and R.W. Van Keuren. 1981. Anthracnose resistance increases alfalfa yields. Crop Sci. 21: 457-460.
Gueldner, R.C., C.C. Reily, P.L. Pusey, C.E. Costello, R.F. Arrendale, R.H. Cox, D.S Himmelsbach, F.G. Crumley, and H.C. Cutler. 1988. Isolation and identification of iturins as antifungal peptides in biological control of peach brown rot with Bacillus subtilis. J. Agric. Food Chem. 36: 366-370.

Jones, E.R., R.B. Caroll, R.H. Swain, and K.W. Bell. 1978. Role of anthracnose in stand thinning of alfalfa in Delaware. Agron. J. 70: 351-353.

Michaud, R., W.F. Lehman, and M.D. Rumbaugh. 1988. World distribution and historical development. Pages 25-91 in A.A. Hanson, D.K. Barnes and R.R. Hill (eds.), Alfalfa and alfalfa improvement. Agronomy Monograph No. 29. American Society of Agronomy, Madison, Wis.

Ostazeski, S.A., D.K. Barnes, and C.H. Hanson. 1969. Laboratory selection of alfalfa for resistance to anthracnose, Colletotrichum trifolii. Crop Sci. 9: 351-354.

Rai, R.P. 1975. In vitro sensivity of Alternaria daturae Peck to the culture filtrate of Bacillus subtilis (Cohn) Prazmowski. Indian J. Exp. Biol. 13: 509-510.

Schreiber, L.R., G.F. Gregory, C.R. Krause, and J.M. Ichida. 1988. Production, partial purification and antifungal activity of a novel antibiotic produced by a Bacillus subtilis isolate from Ulmus americana. Can. J. Bot. 66: 2338-2346.

Snedecor, G.W., and W.G. Cochran. 1980. Statistical methods. 7th Edition. lowa State University Press, lowa. 507 pp.

Vanittanakom, N., W. Loeffler, U. Koch, and G. Jung. 1986. Fengycin - a novel antifungal lipopeptide antibiotic produced by Bacillus subtilis F-29-3. J. Antibiot. 39: 888-901.

Vasudeva,R.S., T.V.Subbiah, G. Rangaswami, and M.R.S. Iyengar. 1958. 'Bulbiformin' an antibiotic produced by Bacillus subtilis. Ann. Appl. Biol. 46: 336.

Willis, C.B. 1965. Observations on the diseases of forage crops in Prince Edward Island. Can. Plant Dis. Surv. 45: 8-11.

Winkelmann, G., H. Allagaier, R. Lupp, and G. Jung. 1983. Iturin $A-$ a new long chain iturin $A$ possessing an unusual high content of C -B-amino acids. J. Antibiot. 36: $1451-1457$. 